Едукација здравствених радника, здравствених и стручних сарадника на тему родно заснованог насиља

\title{
Education of health care professionals, health associates and expert associates on gender-based violence
}

Катарина Боричић

Центар за промоцију здравља, Институт за јавно здравље Србије “Др Милан Јовановић Батут", Београд

ПРИМљЕН 09.12.2019.

ПРИХВАЋЕН 10.02.2020.

\section{АПСТРАКТ}

Циљ. Циљ овог рада је утврђивање квалитета акредитованих едукација на тему родно занованог насиља здравственим радницима, здравственим и стручним сарадницима у Републици Србији.

Методе. Претрагом базе акредитованих програма континуиране едукације објављене на интернет страници Здравственог савета Републике Србије за период од јануара 2010. до јула 2019. године, издвојени су програми коришћењем кључних речи „насиље“, „породица“ „родно засновано“. За испитивање разлика између независних варијабли у односу на зависну варијаблу коришћен је $\chi^{2}$ тест.

Резултати. Овај рад је показао да је две трећине едукација било намењено само здравственим радницима, док је здравственим радницима, здравственим и стручним сарадницима била намењена свака седма едукација. Ако се посматра врста установе, уочава се да је два пута више програма акредитовано од стране организација цивилног друштва у односу на број програма акредитованих од стране здравствених установа. Посматрано према временском периоду у коме су програми акредитовани, може се уочити тренд пораста броја програма. Међу акредитованим програмима, национални курсеви су чинили 42,6\% акредитованих програма, док је сваки други програм био бесплатан. Постоји статистички значајна разлика између едукација које организују различите врсте установа у односу на врсту и цену едукације.

Закључак. Иако се у посматраном периоду уочава тренд пораста броја акредитованих програма који се баве темом родно заснованог насиља, и даље постоји простор за унапређење квалитета континуиране едукације у смислу повећања броја едукација са интерактивним методом рада, едукација намењених различитим профилима како здравствених радника тако и здравствених и стручних сарадника, као и бесплатних online едукација.

Кључне речи: родно засновано насиље; породица; едукација, медицинска, континуирана.

\author{
Katarina Boricic \\ Center for Health Promotion, Institute of Public Health of Serbia "Dr Milan \\ Jovanovic Batut", Belgrade, Serbia \\ RECEIVED 09.12.2019. \\ ACCEPTED 10.02 .2020
}

\section{ABSTRACT}

Objective. The aim of this study is to determine the quality of accredited education on the topic of gender-based violence to health care professionals, health and professional associates in the Republic of Serbia.

Methods. A search of a database of accredited continuing education programs published on the website of the Health Council of the Republic of Serbia for the period between January 2010 and July 2019. identified programs using the keywords "violence", "family" "gender-based". The $\mathrm{Q2}$ test was used to examine the differences between the independent variables versus the dependent variable.

Results. This study showed that two thirds of the training was intended for health care professionals, only while health care workers, health and professional associates were allocated for every seventh education. If the type of institution is observed, it can be noticed that twice as many programs are accredited by civil society organizations in relation to the number of programs accredited by health institutions. Considering the time period in which the programs are accredited, a trend of increasing number of programs can be observed. Among the accredited programs, national courses accounted for $42.6 \%$ of the accredited programs while every other program was free. There is a statistically significant difference between educations organized by different types of institutions in relation to the type and cost of education.

Conclusion. Although in the observed period there is an increasing trend in the number of accredited programs dealing with gender-based violence, there is still room to improve the quality of continuing education in terms of increasing the number of trainings with an interactive method of work, trainings aimed at different profiles of health professionals and health and professional associates, as well as free on line trainings.

Key words: gender-based violence; family; education, medical, continuing. 


\section{увод}

Родно засновано насиље представља једно од најраширенијих кршења људских права у свету и настаје као резултат неравнотеже моћи између мушкараца и жена. Родно засновано насиље је јавно здравствени приоритет са озбиљним последицама по физичко, сексуално, репродуктивно и ментално здравље особе која је претрпела насиље. Починиоци насиља могу бити особе оба пола, али су то најчешће особе женског пола, и то пре свих женске особе које припадају вулнерабилним групама. ${ }^{1}$ Процењена глобална преваленција родно заснованог насиља коју је објавила Светска здравствена организација показује да је 35\% жена широм света доживело насиље у партнерском односу и ван њега. ${ }^{2}$

Када говоримо о преваленцији родно заснованог насиља у Републици Србији, до сада су реализована три истраживања применом различите методологије тако да је тешко поредити податке током времена и на међународном нивоу. Подаци ових истраживања показали су да се укупна преваленција родно заснованог насиља кретала од $18 \%$ до $28 \% .{ }^{3}$ Иако јенасиље и даље табу тема у Србији, о којој се нерадо говори како у јавности тако и међу здравственим радницима, предузете мере на националном нивоу, а пре свега доношење „Посебног протокола Министарства здравља Републике Србије за заштиту и поступање са женама које су изложене насиљу" 2010. године, предвиђају смернице у циљу препознавања, евидентирања и документовања родно засновано насиље од стране здравствених радника, здравствених и стручних сарадника у здравственим установама које се баве здравственом заштитом жена на сва три нивоа здравствене заштите. Лекари одређених специјалности (опште праксе, гинекологије и акушерства, психијатрије), медицинске и патронажне сестре, психолози и социјални радници чине оптимални „Стручни тим за заштиту жена од родно заснованог насиља" у здравственим установама на примарном нивоу здравствене заштите, док у установама вишег нивоа здравствене заштите могу се у тим укључити и лекари других специјалности у зависности од специфичности рада здравствене установе. ${ }^{3}$

Задатак „Стручног тима за заштиту жена од родно заснованог насиља" је да након реализованих едукација здравствених радника, здравствених радника и сарадника у здравственој установи, обавља стручни надзор њиховог рада који треба да је у складу са смерницама „Посебног протокола Министарства здравља Републике Србије за заштиту и поступање са женама које су изложене насиљу". Иако је родно засновано насиље тема која је јавноздравствени приоритет, тренутни садржаји програма додипломске и последипломске наставе се веома оскудно баве овом темом, тако да здравствени радници, здравствени радници и сарадници су након редовног школовања неприпремљени за практичан рад са особама које су жртве родно заснованог насиља. На основу свега реченог, произилази да је веома значајно да се ова тема интегрише у садржај континуиране медицинске едукације како би се што већи број здравствених радника, здравствених радника и сарадника едуковао из ове области и стекао практичне вештине за рад.

Циљ овог рада је утврђивање доступности акредитованих едукација на тему родно занованог насиља здравственим радницима, здравственим и стручним сарадницима у Републици Србији у периоду од јануара 2010 до јула 2019. године.

\section{МАТЕРИЈАЛ И МЕТОДЕ}

На основу претраге базе акредитованих програма континуиране едукације објављене на интернет страници Здравственог савета Републике Србије за период од јануара 2010. до јула 2019. године, издвојени су програми на тему родно заснованог насиља. При претрази су коришћене кључне речи „насиље“, „породица“ „родно засновано“. Период од 2010. године до 2019. године је одређен на основу чињенице да је од 2010. године на снази „Посебни протокол Министарства здравља Републике Србије за заштиту и поступање са женама које су изложене насиљу". Подаци о врсти коморе у којој је програм акредитован, години када је програм акредитован, врсти едукације, циљној групи, месту одржаваља едукације и цени едукације издвојени су као независне варијабле, док је врста установе која је акредитовала програм зависна варијабла. У статистичкој анализи података коришћена је дескриптивна и интерференцијална статистика а подаци су представљени табеларно. Разлика између независних варијабли у односу на зависну варијаблу испитана је коришћењем $\chi 2$ тестА. Ниво статистичке значајности је $\mathrm{p} \leq 0,05$ а статистичка обрада прикупљених података урађена је уз помоћ статистичког програма „IBM Statistical Package for Social Science 22,0". 


\section{РЕЗУЛТАТИ}

Укупно је акредитовано 68 програма континуиране едукације у периоду од јануара 2010. до јула 2019. године. Сваки други програм је акредитован у Лекарској комори Србије (57,4\%), што је за 10\% више програма у односу на број програма акредитованих у комори медицинских сестара и техничара, док ниједан програм на тему родно заснованог насиља није акредитован у фармацеутској и стоматолошкој комори, као ни у бази за здравствене и стручне сараднике (Табела 1 ).

Посматрано према годинама када су програми акредитовани, може се уочити да је највећи број програма акредитован током 2018. године тј. 22,1\% програма, док је најмањи број програма акредитован током 2013. године тј. 1,5\% програма (Табела 1).

Tabela 1. Дистрибуција карактериста континуираних медицинских едукација, Република Србија, период 2010 до 2019. године

\begin{tabular}{|c|c|c|}
\hline Едукација & $n$ & $\%$ \\
\hline \multicolumn{3}{|l|}{ Врста коморе } \\
\hline Лекарска комора & 39 & 57,4 \\
\hline Комора медицинских сестара и техничара & 29 & 42,6 \\
\hline Стоматолошка комора & 0 & 0,0 \\
\hline Фармацеутска комора & 0 & 0,0 \\
\hline База здравствених и стручних сарадника & 0 & 0,0 \\
\hline \multicolumn{3}{|l|}{ Година акредитације } \\
\hline 2010 & 5 & 7,4 \\
\hline 2011 & 6 & 8,8 \\
\hline 2012 & 6 & 8,8 \\
\hline 2013 & 1 & 1,5 \\
\hline 2014 & 6 & 8,8 \\
\hline 2015 & 5 & 7,4 \\
\hline 2016 & 6 & 8,8 \\
\hline 2017 & 13 & 19,1 \\
\hline 2018 & 15 & 22,1 \\
\hline 2019 & 5 & 7,4 \\
\hline \multicolumn{3}{|l|}{ Врста установе } \\
\hline Здравствена установа & 24 & 35,3 \\
\hline $\begin{array}{l}\text { Здравствена установа примарног нивоа } \\
\text { здравствене заштите (дом здравља, } \\
\text { завод) }\end{array}$ & 14 & 58,3 \\
\hline Здравствени центар & 1 & 4,2 \\
\hline Здравствена установа терцијарног нивоа & 7 & 29,2 \\
\hline $\begin{array}{l}\text { Здравствена установа на сва три нивоа } \\
\text { здравствене заштите (институт/завод за } \\
\text { јавно здравље) }\end{array}$ & 2 & 8,3 \\
\hline Организације цивилног друштва & 44 & 64,7 \\
\hline Удружења грађана & 10 & 22,7 \\
\hline Струковна удружења, друштва, савези & 34 & 77,3 \\
\hline
\end{tabular}

Ако се посматра врста установе која је организатор програма континуиране едукације, уочава се да је највећи број програма акредитовано од стране организација цивилног друштва односно $64,7 \%$ програма, што је скоро два пута више у односу на број програма акредитованих од стране здравствених установа. Међу организацијама цивилног друштва, струковна удружења/савези/друштва су акредитовали највећи број програма $(77,3 \%)$ а удружења грађана најмањи $(22,7 \%)$, док су здравствене установе примарног нивоа здравствене заштите (58,3\%) имали највећи број акредитованих програма, а здравствени центри најмањи $(4,2 \%)$ (Табела 1$)$.

Међу акредитованим програмима, највећи број програма су представљали национални курсеви $(42,6 \%)$, док је најмањи број програма акредитован као национални конгрес или симпозијум (4,4\%). Стручни састанци су чинили 38,2\% акредитованих програма (Табела 1). Скоро два пута више акредитованих програма је намењено реализацији едукација на окружном нивоу $(61,8 \%)$ у односу на број програма на националном нивоу.

Скоро подједнак број програма је предвидео да учесници плаћају (48,5\%) односно не плаћају (51,5\%) похађање едукације. Међу програмима који субесплатни за учеснике едукације, $72,4 \%$ је било потпуно бесплатно, док је 28,6\% едукација било потпуно бесплатно само за чланове удружења (Табела 2).

Посматрајући циљну групу којој је била намењена едукација, највећи број едукација је био намењен здравственим радницима високе, више и средње стручне спреме (69,1\%), док је здравственим радницима и сарадницима била намењена свака шеста едукација, а здравственим радницима, здравственим и стручним сарадницима свака седма едукација (Табела 2). 
Tabela 2. Дистрибуција карактериста континуираних медицинских едукација, Република Србија, период 2010 до 2019. године, према врсти, циљној групи, месту одржавања и цени.

\begin{tabular}{|c|c|c|}
\hline Едукација & $n$ & $\%$ \\
\hline \multicolumn{3}{|l|}{ Врста едукације } \\
\hline Национални курс & 29 & 42,6 \\
\hline Стручни састанак & 26 & 38,2 \\
\hline Тест & 10 & 14,7 \\
\hline Национални конгрес, симпозијум & 3 & 4,4 \\
\hline \multicolumn{3}{|l|}{ Циљна група } \\
\hline Здравствени радници & 47 & 69.1 \\
\hline Здравствени радници и сарадници & 11 & 16.2 \\
\hline $\begin{array}{l}\text { Здравствени радници, здравствени } \\
\text { сарадници и }\end{array}$ & 6 & 8,8 \\
\hline Стручни сарадници & 10 & 14.7 \\
\hline \multicolumn{3}{|l|}{ Место одржавања едукације } \\
\hline Национални ниво & 26 & 38,2 \\
\hline Окружни ниво & 42 & 61,8 \\
\hline \multicolumn{3}{|l|}{ Цена едукације } \\
\hline Са надокнадом & 33 & 48,5 \\
\hline Без надокнаде & 35 & 51,5 \\
\hline
\end{tabular}

Ако посматрамо дистрибуцију карактериста континуираних медицинских едукација према врсти установе, уочава се да је свака друга едукација коју организује здравствена установа национални курс или стручни састанак, док ниједна едукација није организована као тест или национални конгрес/ симпозијум, док је свака трећа едукација коју организује организација цивилног друштва национални курс а најређе су едукације организоване као национални конгрес/симпозијум. Најчешће су едукације које организује здравствена установа бесплатне (70,8\%), за разлику од организација цивилног друштва чије се едукације најчешће плаћају $(59,1 \%)$ (Табела 3 ).

Ако посматрамо циљну групу и место одржавања едукације, здравствене установе најчешће организују едукације намењене здравственим радницима $(75,0 \%)$ и то едукације на окружном нивоу $(75,0 \%)$, а најређе едукације намењене здравственим радницима, здравственим сарадницима и стручним сарадницима $(8,3 \%)$ и едукације на националном нивоу (25,0\%), што је идентично и када се посматрају организације цивилног друштва (Табела 3).
Tabela 3. Дистрибуција карактериста континуираних медицинских едукација према врсти установе, Република Србија, период 2010 до 2019. године

\begin{tabular}{|c|c|c|c|}
\hline \multirow{3}{*}{ Варијабле } & \multicolumn{2}{|c|}{ Врста установе } & \multirow{2}{*}{ 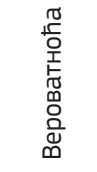 } \\
\hline & $\begin{array}{l}\text { Здравствена } \\
\text { установа }\end{array}$ & $\begin{array}{c}\text { Организација } \\
\text { цивилног } \\
\text { друштва }\end{array}$ & \\
\hline & n (\%) & n (\%) & $p$ \\
\hline \multicolumn{4}{|l|}{ Врста едукације } \\
\hline Национални курс & $12(50,0 \%)$ & $17(38,6 \%)$ & \multirow{4}{*}{0,031 * } \\
\hline Стручни састанак & $12(50,0 \%)$ & $14(31,8 \%)$ & \\
\hline Тест & $0(0,0 \%)$ & $10(22,7 \%)$ & \\
\hline $\begin{array}{l}\text { Националниконгрес/ } \\
\text { симпозијум }\end{array}$ & $0(0,0 \%)$ & $3(6,8 \%)$ & \\
\hline \multicolumn{4}{|l|}{ Циљна група } \\
\hline Здравствени радници & $18(75,0 \%)$ & $29(65,9 \%)$ & \multirow{3}{*}{$0,545^{*}$} \\
\hline $\begin{array}{l}\text { Здравствени радници } \\
\text { и сарадници }\end{array}$ & $4(16,7 \%)$ & $7(15,9 \%)$ & \\
\hline $\begin{array}{l}\text { Здравствени } \\
\text { радници, здравствени } \\
\text { сарадници и стручни } \\
\text { сарадници }\end{array}$ & $2(8,3 \%)$ & $8(18,2 \%)$ & \\
\hline \multicolumn{4}{|l|}{ Место одржавања } \\
\hline Национални ниво & $6(25,0 \%)$ & $20(45,5 \%)$ & \multirow{2}{*}{0,097 * } \\
\hline Окружни ниво & $18(75,0 \%)$ & $24(54,5 \%)$ & \\
\hline \multicolumn{4}{|l|}{ Цена едукације } \\
\hline Са надокнадом & $7(29,2 \%)$ & $26(59,1 \%)$ & \multirow{2}{*}{0,018 * } \\
\hline Без надокнаде & $17(70,8 \%)$ & $18(40,9 \%)$ & \\
\hline
\end{tabular}

${ }^{\star} \chi 2$ тест

Када варијабле које се односе на врсту едукације, циљну групу којој је намењена едукација, место одржавања едукације и цену едукације анализирамо према врсти установе која је организатор едукације, уочава се да постоји статистички значајна разлика када се посматра врста и цена едукације (Табела 3).

\section{ДИскУсИЈА}

Током протекле деценије дошло је до одређеног напретка у спровођењу програма обуке на тему родно заснованог насиља за здравствене раднике, здравствене и стручне сараднике, с циљем да се побољша њихова способност пружања помоћи подршке особама које су преживеле насиље. ${ }^{4}$ Међутим, и даље се води полемика око тога да ли треба радити рутински скрининг за насиље у породици, посебно када су ресурси ограничени. Истраживања показују да се здравствени радници, здравствени и стручни сарадници суочавају са изазовима приликом спровођења превентивних мера, због неадекватне обуке која није задовољила мултидисциплинарни приступ, као и због недостатка времена, искуства, свести о ресурсима у заједници и доступности ефикасних интервенција за подршку женама и пружање даље заштите., Истраживања о ефикасности тренинга у оквиру постдипломске и 
континуиране медицинске едукације сугеришу да такве активности побољшавају знање и ставове лекара о насиљу у породици, али пружају ограничене доказе да едукативне активности утичу на крајње исходе по пацијента. ${ }^{4,7,8}$ Захер и сарадници су у својој студији која представља систематски преглед литературе контролисаних рандомизованих студија, дошли до резултата да се знање лекара о насиљу у породици може значајно побољшати образовним интервенцијама које укључују активно учешће лекара и искуствено учење. ${ }^{9}$ Неке студије су показале да интерактивне радионице мењају ставове и перформансе клиничара и утичу на њихове свакодневне праксе за управљање особама које су преживеле насиље. ${ }^{10,11}$

Са друге стране, радионице о насиљу у породици, у оквиру посдипломске наставе, нису дале значајан ефекат на њихово понашање у откривању особа које су претрпеле родно засновано насиље. ${ }^{12-15}$ Идентификација и управљање породичним насиљем није процес у једном кораку. Идентификација и управљање насиљем у породици може бити емоционално искуство не само за пацијента, већ и за пружаоца услуга, а неке студије су захтевале више од кратке интервенције за побољшање способности лекара за препознавање и управљање случајевима породичног насиља. ${ }^{16,17}$ Употреба сценарија са моделима типичних пацијената који су преживели насиље као саставни део обуке лекара на последипломској настави, је унапредила је њихово знање и вештине, што је резултирало већим бројем пријављених случајева насиља у породици. ${ }^{18}$

Резултат ове студије је показао да су национални курсеви чинили 42,6\% акредитованих програма, као једину врсту едукације која предвиђа интерактивни радионичарски рад. Претходни систематски прегледи показују да е-учење може побољшати знање и вештине лекара, што резултира одрживим променама у понашању, у поређењу са едукацијама које садрже и радионичарски рад. ${ }^{16,19,20}$ У систематском прегледу показано је да је резултат две контролисане рандомизоване студије, у којима су коришћени интерактивни, веб дизајнирани модули, значајно побољшало знања и способности лекара да препозна и води случајеве насиља у породици.,14,21 Међутим, дугорочни исходи на стварну промену понашања лекара и исходи у вези са перформансама здравствене заштите пацијената, као и исплативост оваквог начина учења, захтева даље истраживање. ${ }^{22}$ Резултат проистекао у овом раду да сваки други акредитован програм предвиђа да учесници плаћају похађање едукације, и то статистички чешће уколико је едукација организована од стране организација цивилног друштва, указује на чињеницу неопходности увођења бесплатних е-обука којима ће се обухватити већи број учесника који су прошли едукацију.

У једном систематском прегледу, аутори су показали да су битни елементи ефикасне едукације били мултидисциплинарни тренинзи лекара са сесијама њиховог оснаживања у пружању подршке, у комбинацији са додатном обуком за вође и шампионе тимова, као и интервенције подршке у локалној заједници, попут повећања свести о родно заснованом насиљу у локалној заједници, подсетници за идентификацију особа које су преживеле насиље и побољшани приступ услугама подршке. ${ }^{9}$ То је потврдио и овај рад. Наиме, овај рад је указао на значај мултидисциплинарног и мултисекторског приступа при дизајнирању програма едукације, што је проистекло из добијеног резултата да сваки седми програм акредитован за здравствене раднике, здравствене и стручне сараднике у здравственим установама и локалној заједници.

Рад је показао да је две трећине едукација било намењено здравственим радницима, док је здравственим радницима, здравственим и стручним сарадницима била намењена свака седма едукација. Из свега наведеног произилази предлог да се мотивишу здравствени радници и сарадници или пак њихова струковна удружења са циљем акредитације више програма намењених здравственим и стручним сарадницима као што су психолози и социјални радници, а који су уједно и део Стручних тимова у здравственим установама и чија је улога веома значајна у превенцији, препознавању, процени и реаговању на насиље.

Ако се посматра врста установе која је организатор програма континуиране едукације, уочава се да је скоро два пута више програма акредитовано од стране организација цивилног друштва у односу на број програма акредитованих од стране здравствених установа. Међу здравственим установама, највећи број програма је акредитован од стране здравствених установа на примарном нивоу здравствене заштите, што указује на чињеницу да треба унапредити акредитацију едукација намењених здравственим радницима, здравственим и стручним сарадницима на секундарном и терцијарном нивоу здравствене заштите. Међу организацијама цивилног друштва, три четвртине едукација је акредитовано од стране струковних удружења/савеза/друштва, а свега једна четвртина од стране удружења грађана односно невладиних организација, што намеће потребу мотивисања невладиног сектора да акредитује више програма из ове области, који ће бити намењени ефикасној комуникацији и сарадњи различитих сектора у локалној заједници (полиције, центара за социјални рад, правосуђа, здравственог сектора, сектора цивилног друштва). Такође, организације цивилног друштва статистички чешће организују различите врсте едукације, са или без надокнаде у односу на здравствене установе.

Међу акредитованим програмима, национални курсеви су чинили 42,6\% акредитованих програма, што указује на чињеницу да треба мотивисати организаторе едукације да у што већем броју акредитују 
ову врсту едукације, јер поред ове врсте едукације осим предавања, једина предвиђа и интерактиван радионичарски рад. Сваки други програм је предвидео да учесници плаћају похађање едукације, што указује на потребу размишљања о басплатној е-обуци на даљину, јер би се на тај начин повећао број бесплатних програма и обухватио већи број здравствених радника, здравствених и стручних сарадника који су прошли обуку.

Можемо закључити да је у периоду од усвајања „Посебног протокола Министарства здравља Републике Србије за заштиту и поступање са женама које су изложене насиљу", до данас, интензивирана акредитација програма на тему родно заснованог насиља. Међутим, тренд пораста броја програма у посматраном периоду није био континуиран, што указује на чињеницу да треба континуирано заговарати родно засновано насиље као приоритетну тему јавног здравља.

\section{ЛИТЕРАТУРА}

1. World Health Organization, London School of Hygiene and Tropical Medicine, South African Medical Research Council. Global and regional estimates of violence against women: prevalence and health effects of intimate partner violence and non-partner sexual violence. Geneva: WHO, 2013.

2. UNFPA and WAVE. Strengthening health system responses to gender based violence in Eastern Europe and Central Asia: a resource package. Vienna: UNFPA Regional Office for Eastern Europe and Central Asia, Turkey and WAVE Network and European Info Centre against Violence, 2014.

3. Министарство здравља Републике Србије. Посебан протокол Министарства здравља Републике Србије за заштиту и поступање са женама које су изложене насиљу. Београд: Министарство здравља Републике Србије, 2010.

4. Hamberger LK. Preparing the next generation of physicians: medical school and residency-based intimate partner violence curriculum and evaluation. Trauma Violence Abuse 2007; 8: 214-25.

5. Yeung H, Chowdhury N, Malpass A, Feder GS. Responding to domestic violence in general practice: a qualitative study on perceptions and experiences. Int J Family Med 2012; 2012: 960523.

6. Sprague S, Madden K, Simunovic N, et al. Barriers to screening for intimate partner violence. Women Health 2012; 52: 587-605.

7. Korenstein D, Thomas DC, Foldes C, Ross J, Halm E, McGinn T. An evidence-based domestic violence education program for internal medicine residents. Teach Learn Med 2003;15: 262-6.

8. McColgan MD, Cruz M, McKee J, et al. Results of a multifaceted intimate partner violence training program for pediatric residents. Child Abuse Negl 2010; 34: 275-83.

9. Zaher E, Keogh K, Ratnapalan S. Effect of domestic violence training: systematic review of randomized controlled trials. Can Fam Physician 2014; 60: 618-24, e340-7.

10. Haney K, Kachur E, Zabar S. A brief but multi-faceted approach improves clinicians' domestic violence confidence, competence and clinical performance. Med Educ 2003; 37: 488-9.

11. Kripke EN, Steele G, O'Brien MK, Novack DH. Domestic violence training program for residents. J Gen Intern Med 1998; 13: 839-4.

12. Lo Fo Wong S, Wester F, Mol SS, Lagro-Janssen TL. Increased awareness of intimate partner abuse after training: a randomised controlled trial. Br J Gen Pract 2006; 56 : 249-57.

13. Coonrod DV, Bay RC, Rowley BD, et al. A randomized controlled study of brief interventions to teach residents about domestic violence. Acad Med 2000; 75: 55-7.

14. Harris JM, Jr, Kutob RM, Surprenant ZJ, Maiuro RD, Delate TA. Can internet-based education improve physician confidence in dealing with domestic violence? Fam Med 2002; 34: 287-92.

15. Brienza RS, Whitman L, Ladouceur L, Green ML. Evaluation of a women's safe shelter experience to teach internal medicine residents about intimate partner violence. A randomized controlled trial. J Gen Intern Med 2005; 20: 536-40.

16. Fordis M, King JE, Ballantyne CM, et al. Comparison of the instructional efficacy of Internet-based CME with live interactive CME workshops: a randomized controlled trial. JAMA 2005; 294: 1043-51.

17. McCluskey A, Lovarini M. Providing education on evidence-based practice improved knowledge but did not change behaviour: a before and after study. BMC Med Educ 2005; 5: 40.

18. Shefet D, Dascal-Weichhendler H, Rubin O, et al. Domestic violence: a national simulation-based educational program to improve physicians' knowledge, skills and detection rates. Med Teach 2007; 29: e133-8.

19. Cook DA, Levinson AJ, Garside S, Dupras DM, Erwin PJ, Montori VM. Internet-based learning in the health professions: a meta-analysis. JAMA.2008; 300: 1181-96.

20. Cook DA, Levinson AJ, Garside S, Dupras DM, Erwin PJ, Montori VM. Instructional design variations in internet-based learning for health professions education: a systematic review and meta-analysis. Acad Med. 2010; 85: 909-22.

21. Short LM, Surprenant ZJ, Harris JM Jr. A community-based trial of an online intimate partner violence CME program. Am J Prev Med.2006; 30: 181-5.

22. Harris JM Jr, Novalis-Marine C, Amend RW, Surprenant ZJ. Promoting free online CME for intimate partner violence: what works at what cost?. J Contin Educ Health Prof 2009; 29: 135-41. 